OPEN ACCESS

Edited by:

Simon Jungblut,

University of Bremen, Germany

Reviewed by:

Karim Erzini,

University of Algarve, Portugal

Colin David Buxton,

University of Tasmania, Australia

${ }^{*}$ Correspondence: Michael Kriegl

michael.kriegl@outlook.com

Specialty section:

This article was submitted to Marine Conservation

and Sustainability,

a section of the journal

Frontiers in Marine Science

Received: 04 March 2021

Accepted: 04 May 2021

Published: 08 June 2021

Citation:

KriegI M, Elías Ilosvay XE, von Dorrien $C$ and Oesterwind $D$

(2021) Marine Protected Areas: At

the Crossroads of Nature

Conservation and Fisheries

Management.

Front. Mar. Sci. 8:676264. doi: 10.3389/fmars.2021.676264

\section{Marine Protected Areas: At the Crossroads of Nature Conservation and Fisheries Management}

\author{
Michael Kriegl1,2*, Xochitl E. Elías Ilosvay ${ }^{3}$, Christian von Dorrien ${ }^{1}$ and \\ Daniel Oesterwind ${ }^{1}$
}

1 Thünen Institute of Baltic Sea Fisheries, Rostock, Germany, ${ }^{2}$ Leibniz Centre for Tropical Marine Research (ZMT), Bremen, Germany, ${ }^{3}$ Centro de Investigación Mariña, Universidade de Vigo, Future Oceans Lab, Vigo, Spain

Marine protected areas (MPAs) are designated parts of the ocean that restrict human activities to a certain degree. MPAs are established around the world using a wide range of legislative instruments and thus come in a variety of forms and shapes. Despite being regarded as the "cornerstone" of global marine conservation efforts, they currently cover less than $10 \%$ of the ocean surface. Individual MPAs aim to achieve goals ranging from the protection of specific habitats or species to sustaining certain commercial activities, such as fishing. By default, the establishment of MPAs intertwines social, ecological and economic considerations. Yet, the emphasis put on each of these domains can vary substantially when setting on-the-ground objectives, frequently creating conflict among stakeholders. In this manuscript, we first discuss current international conservation targets as well as potential future goals and delve into the question of how to assess the effectiveness of MPAs. Subsequently, we discuss the ambivalent role of this widely applied management tool at the crossroads between biodiversity conservation and fisheries management. Placing MPAs in a social-ecological framework, we call for clear and measurable goals to evaluate MPAs from an interdisciplinary perspective. Finally, we present the Baltic Sea, with its high degree of anthropogenic impact, long fishing history and comparatively extensive MPA coverage, as an interesting case study to investigate the role of MPAs in promoting a sustainable management of the ocean.

\footnotetext{
Keywords: marine protected areas, fisheries management tools, marine conservation, sustainable ocean management, effectiveness assessment, social-ecological systems, stakeholder engagement, Baltic Sea
}

\section{INTRODUCTION}

Humans have extracted living marine resources from the ocean for centuries (Jackson et al., 2001; Lotze et al., 2006; Worm et al., 2006). Marine fisheries are highly important for global food security, with fish accounting for about $17 \%$ of the global population's animal protein intake, and provide livelihoods to millions of people around the world (FAO, 2020a). Fisheries also have a huge economic importance (annual value of marine fisheries landings at first sale around $\$ 80$ billion; Dyck and Sumaila, 2010), with approximately 40 million people being directly employed (FAO, 2020b) and another estimated 200 million having occupations indirectly linked with this sector (Teh and Sumaila, 2011). About nine out of ten people working in the capture fisheries value chain are associated with the small-scale fisheries sector (Worldbank, 2012). 
Fisheries, by default, have an impact on the marine realm and, today, exert one of the most widespread anthropogenic impacts on marine ecosystems (Butchart et al., 2010; RamirezLlodra et al., 2011; Halpern et al., 2012). As such, fishing is often regarded as a key threatening process to marine environments (Jennings and Kaiser, 1998; Lubchenco et al., 2003; Crowder et al., 2008) and potentially exacerbates the effects of other global stressors (such as climate change; Ojea et al., 2017). If done in an unsustainable manner, the exploitation of living marine resources can negatively influence the services that the ocean provides (Crowder et al., 2008). To regulate this potential impact, several management tools, such as gear restrictions, fishing quotas and area closures (temporal and spatial) are employed around the world (Worm et al., 2009). Marine protected areas (MPAs), specifying particular sections of the ocean where human activities, such as fishing, are restricted to varying degrees, are often advertised as a particularly effective tool to safeguard marine biodiversity from anthropogenic activities (Gaines et al., 2010; Halpern et al., 2010; Duarte et al., 2020).

The global extent of MPAs has increased steadily and substantially in recent years (Humphreys and Clark, 2020). Scholars identify MPAs as the "primary tool" (Devillers et al., 2019), "cornerstone" (Giakoumi et al., 2018) and "key component" of global marine conservation strategies (Lubchenco et al., 2003; Gaines et al., 2010) and highlight their role for rebuilding life in the ocean (Duarte et al., 2020). With voices from the academic community and especially the conservation sector in favor of increasing the share of MPAs getting louder (Sala et al., 2021), their importance is likely to increase in the future. Yet, there are multiple social, economic and political challenges associated with the establishment of ever new MPAs and the so called "triple bottom line" (Rees et al., 2018)_ integrating economic growth, environmental sustainability and social justice-may not be achievable (Gaines et al., 2010; but see Sumaila et al., 2012). Potential challenges include the difficulty of enforcement of set rules (Wilhelm et al., 2014), lack of political will (Kati et al., 2014) and diverging objectives of stakeholders (Kaiser, 2005). As trade-offs become evident, there is an increased interest toward finding strategies that synergize the conservation and exploitation of marine ecosystems and resources.

The scientific literature documented that-under certain ecological settings and specific management circumstances (discussed below)-MPAs can be highly beneficial for certain species and habitats occurring within their boundaries (Humphreys and Clark, 2020). Overall, MPAs were found to increase biological parameters of species, such as abundance and size of individuals, within the protected area (Lester et al., 2009; Gaines et al., 2010). Despite a strong consensus about the positive impact of MPAs within the conservation sector, their general appropriateness for fisheries management is still under debate, as depicted by a growing concern over the usefulness of this management tool (Kaiser, 2005; Hilborn, 2016, 2018). As MPAs are continuously being declared around the globe, tensions between the conservation and resource exploitation sector are rising, while the effectiveness and even legitimacy of MPAs are still unclear (Kearney et al., 2012; Cormier-Salem, 2014). It is therefore essential to use sound scientific evidence to identify and effectively communicate the factors that influence MPA effectiveness for each individual case (Pendleton et al., 2018). Furthermore, clear and measurable conservation objectives and management targets have to be set and evaluated within solid monitoring schemes. Agreeing on a common language helps to avoid confusion in cases where stakeholders with diverse backgrounds are involved in the MPA process and employing a clearly structured evaluation framework, similar to the Drivers-Pressures-State-Impact-Response framework (DPSIR), may support this process (e.g., Gabrielsen and Bosch, 2003; Oesterwind et al., 2016).

Here we shed light on the objectives of MPAs from different viewpoints and discuss international ambitions to protect a predefined share of the ocean within MPAs. Subsequently, we examine how the effectiveness of MPAs is commonly assessed and discuss the ambivalent role of this widely applied management tool at the crossroads between biodiversity conservation and fisheries management. Acknowledging the role of MPAs as socialecological entities, we highlight the importance of clear and measurable targets within an interdisciplinary MPA evaluation framework. Finally, we explain why the Baltic Sea, with its historic importance for regional fisheries, high levels of anthropogenic impact and comparatively large fraction of MPA coverage, is a particularly interesting sea basin to investigate the role of MPAs in promoting a sustainable management of the ocean.

\section{What Is a Marine Protected Area and How Many Are There?}

Marine protected areas come in a variety of forms and shapes. They vary in purpose, management approaches and regulations, resulting in different levels of protection as well as restrictions of human uses (Horta e Costa et al., 2016). Some MPAs are designed to exclude all types of extractive human activities (so-called no-take MPAs, occasionally referred to as (no-take) "marine reserves"), while others are managed as multi-use MPAs that aim to sustain certain commercial and/or recreational activities (e.g., fisheries management areas), are designated to conserve specific species or habitats (e.g., species management areas) or act as recreational areas (e.g., protected seascapes) (Day et al., 2012). These MPAs span the diversity of marine ecosystems, ranging from estuaries to coastal zones and the open ocean. MPAs are set up by numerous different national and international entities utilizing a variety of distinct legislative instruments (Humphreys and Clark, 2020) and pursue a multitude of diverging goals. In this context, the classification of MPAs is a highly controversial (and political) issue (Caveen et al., 2015). A variety of different classification systems have thus been put forward, such as the IUCN MPA protection classification (Day et al., 2012), the regulation-based classification system for MPAs (Horta e Costa et al., 2016) or the MPA guide ${ }^{1}$ (currently in scientific review for publication).

A commonly used definition of MPAs comes from the International Union for the Conservation of Nature (IUCN) (see Kelleher, 1999), which describes a marine protected area as "any area of intertidal or subtidal terrain, together with its overlying

\footnotetext{
${ }^{1}$ https://www.protectedplanet.net/c/mpa-guide/ (last accessed on 05.04.2021).
} 
water and associated flora, fauna, historical and cultural features, which has been reserved by law or other effective means to protect part or all of the enclosed environment" (Humphreys and Clark, 2020). Other definitions, such as the one adopted by the World Wide Fund for Nature (WWF) puts more emphasis on the role MPAs should fulfill, by defining MPAs as "areas designated and effectively managed to protect marine ecosystems, processes, habitats and species, which can contribute to the restoration and replenishment of resources for social, economic and cultural enrichment" (Reuchlin-Hugenholtz and McKenzie, 2015, p. 5).

The Aichi Biodiversity Targets of the Convention on Biological Diversity $^{2}$ call for $10 \%$ of the coastal and marine areas to be conserved through "effectively and equitably managed, ecologically representative and well connected systems of protected areas and other effective area-based conservation measures" by the end of 2020 (a goal originally established for the end of 2010, but postponed in the same year; CBD, 2010, Aichi target 11, Humphreys and Clark, 2020). The United Nations Sustainable Development Goals reiterated this 10\% target for 2020 (SDG 14.5), in order to "conserve and sustainably use the oceans, seas and marine resources for sustainable development". Writing this article at the beginning of 2021, how far have we come? As of April 2021, IUCN's World Database of Protected Areas $^{3}$ and the Marine Protection Atlas ${ }^{4}$, two primary sources for global and regional marine protected area coverage statistics, report 7.7 and $6.4 \%$ global marine coverage, respectively.

In order to properly estimate the coverage of MPAs and assess their effective contribution to ocean conservation (as opposed to the role of so called "paper parks"), a standardized protocol specifying which areas qualify as an effective MPA and are thus counted toward coverage targets has to be agreed upon (Humphreys and Clark, 2020). In fact, the lack of such a protocol explains much of the discrepancy commonly arising in discussions around MPA coverage objectives (see above). In contrast to the IUCN World Database of Protected Areas, the Marine Protection Atlas for example specifically excludes both designated/unimplemented (0.6\%) as well as proposed/committed MPAs (1.4\%) and thus provides a more conservative estimate of global MPA coverage. Nonetheless, if all of these designated and proposed areas would be implemented, the global target of $10 \%$ would still not be reached yet (cf. Figure 1A).

Besides the size of a marine protected area and the characteristics of the protected ecosystem component, the degree of protection can have high relevance for the success of an MPA (of course depending on how "success" is defined for individual MPAs; Edgar et al., 2014). This raises the question if-when chasing after percentages of coverage - the quantity of MPAs may be incentivized over their quality. In this context, several scholars call for caution and criticize that a large share of MPAs lack management plans, allow different types of extractive activities and are often neither enforced nor monitored (Rife et al., 2012; Lubchenco and Grorud-Colvert, 2015). These scholars thus call

\footnotetext{
${ }^{2}$ https://www.cbd.int/sp/targets/ (last accessed on 05.04.2021).

${ }^{3}$ https://www.protectedplanet.net/(last accessed on 05.04.2021).

${ }^{4}$ https://www.MPAtlas.org/(last accessed on 05.04.2021).
}

for an increase in the share of (well-enforced and managed) notake MPAs, which currently cover less than $1 \%$ of the global ocean. Depending on the local circumstances and aims, the establishment of no-take MPAs, however, may not always be the adequate solution. Restrictions of human activities within a particular MPA certainly have to be well-aligned with its specific conservation goals, considering the damaging aspects of locally relevant extractive activities, such as fishing. Furthermore, one has to keep in mind that the key threats for the ocean are of diverse nature, including factors such as sedimentation, plastic pollution, oil spills, climate change, eutrophication and the risk of introduced pests, which are only rarely addressed in the context of MPAs.

\section{How Much Is Enough? Determining the Size of the Cake for MPAs}

Implementing MPAs and thereby restricting access and/or freedom of action for resource users (that are historically accustomed to open-access regimes) understandably yields the potential for injustice and conflict (Jones, 2009). Possible negative socio-economic impacts of MPAs on local communities include loss of income, decreased food security, displacement from traditional harvest grounds as well as increased social tension and political struggles (Bennett and Dearden, 2014; Sowman and Sunde, 2018). Such adverse effects on people's culture, way of life and sense of place can in turn negatively influence conservation outcomes. Consequently, the question is, what fraction of the ocean within MPAs would be adequate to support conservation goals, while minimizing (or even reversing) the possible negative impact on resource users, such as fishers? In other words, when do conservation benefits of MPAs outweigh the potentially lost "value" for those groups depending on these areas (see White, 2009)? Answering this question has been described as the "Holy Grail" of marine protection (Lubchenco et al., 2003).

In 2014, the IUCN World Parks Congress recommended to "urgently increase the ocean area in ecologically representative and well-connected systems of MPAs or other effective conservation measures by 2030; these should include strictly protected areas that amount to at least $30 \%$ of each marine habitat and address both biodiversity and ecosystem services" (WPC, 2014). This goal is in line with studies that have concluded that protecting about one third of the ocean would be ideal from a fisheries perspective (Botsford et al., 2001; Gaines et al., 2010; but see Kaiser, 2005) as well as from a conservation point of view (Sala et al., 2002; Airamé et al., 2003; Beger et al., 2003; Gladstone, 2007; Gaines et al., 2010; for a meta-analysis see O'Leary et al., 2016). This target has recently been reiterated as the so-called $30 \times 30$ MPA target $(30 \%$ MPA coverage, with 10\% strictly protected, by 2030), which is strongly supported by the European Commission's Green Deal (EU Biodiversity Strategy for 2030) as well as an increasing number of countries around the globe. Considering the current rate of global biodiversity loss, some scholars even call for $50 \%$ protected area coverage ("half-earth" scenario) in the ocean, ideally being entirely off-limits to fishing (e.g., Wilson, 2016; but see Humphreys and Clark, 2020 for a discussion on the feasibility of this proposition). Whatever the 

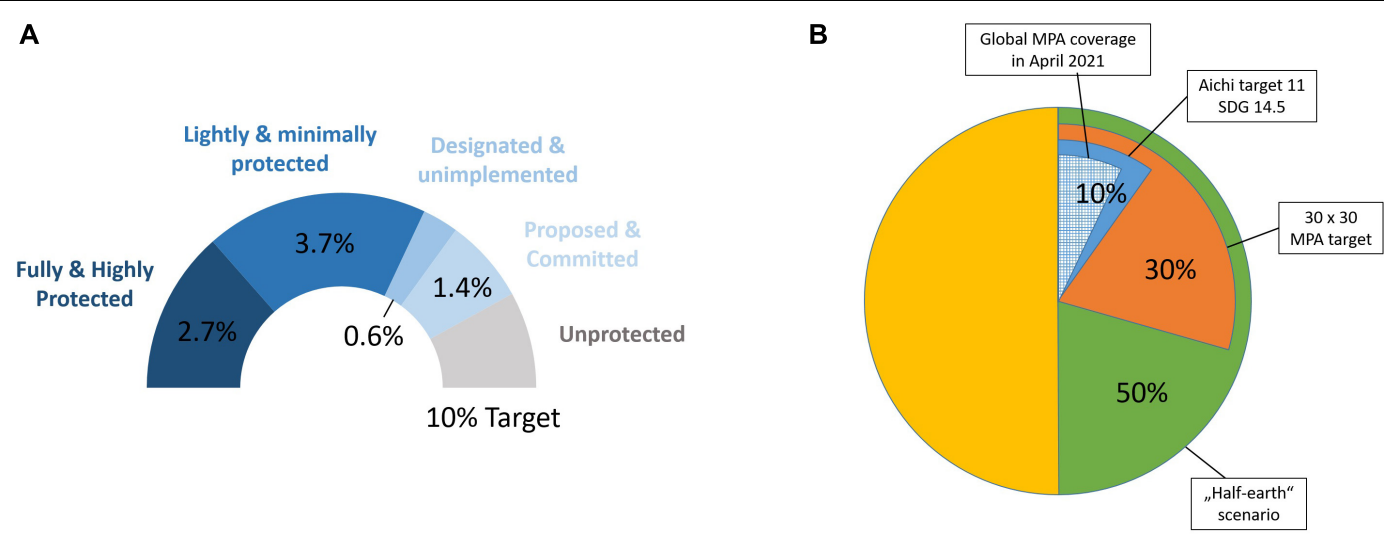

FIGURE 1 | Global marine protected area (MPA) coverage and potential international targets. (A) Share of global ocean covered by MPAs of different designation categories in April 2021. (B) Share of global MPA coverage in relation to potential future MPA coverage targets. Based on data from MPAtlas.org, accessed on April 4th 2021.

"magic number" is (cf. Figure 1B), the coverage of MPAs is likely to be scaled up in the near future, inherently entailing the risk of incentivizing quantity over quality.

\section{SUCCESS BEYOND PERCENTAGES: HOW TO ASSESS THE EFFECTIVENESS OF MPAs?}

As MPAs are increasingly used as management tools around the globe, the imminent question is, are they achieving their goals? A vast body of scientific literature aims to answer this question by looking at the biological response of marine ecosystems to MPA establishment, focusing on temporal effects (e.g., Halpern and Warner, 2002; Russ et al., 2008), species that profit (Russ et al., 2004; White and Kendall, 2007) and species that do not benefit from MPAs (Hilborn et al., 2004; Hart, 2006; Kaplan, 2009) as well as cascading effects within local food webs (Baskett, 2006; Buxton et al., 2006; Baskett et al., 2007). Common biological metrics to empirically assess the effectiveness of MPAs are: abundance (i.e., density of individuals per area), biomass, size of individuals and diversity (i.e., species richness) (for a review and metaanalysis see Woodcock et al., 2017). These factors are usually compared for inside vs. outside the MPA and/or before vs. after the implementation of spatial protection measures and a relative increase in the aforementioned metrics is commonly expected for MPAs (White et al., 2011). A global meta-analysis of empirical studies found that these parameters usually increase inside notake MPAs, but can, however, also decrease in individual cases (Lester et al., 2009; see also Halpern and Warner, 2002; Halpern et al., 2004). On the theoretical side, several modeling exercises also suggest overall positive responses of MPA establishment on the biological metrics for a variety of species (see Gaines et al., 2010 for a meta-analysis of modeling studies).

In general, MPAs seem to be able to deliver what they promise in terms of certain biological metrics. On the level of individual MPAs, however, the range of empirical biological responses has been found to be "enormous" (Gaines et al., 2010). Raising the question, what causes some MPAs to perform better than others? Overall, the effectiveness of MPAs based on biological metrics was found to be positively correlated with size, age, level of protection, enforcement and connectivity (Claudet et al., 2008, 2010; Edgar et al., 2014). Particularly, MPAs that do not allow extractive activities (i.e., no-take MPAs) have been shown to foster biodiversity conservation (Sciberras et al., 2013; Edgar et al., 2014; Sala et al., 2018), while some scholars highlight the role of partially protected areas as a compromise in situations, where a total ban of extractive activities is not a socio-economically and/or politically viable option (Sciberras et al., 2013; Harasti et al., 2018). It is clear that the potential benefits (as well as goals) of individual MPAs depend on a variety of factors specific to the locality, such as the ecological setting of the system, past and future exploitation levels (e.g., fishing pressure) in the area, the state of the fished populations in the areas surrounding MPAs (i.e., efficacy of the fisheries management in the wider area, see Buxton et al., 2014; Hilborn, 2016), the political context in which the marine protected area is set (influencing MPA design and management) as well as the life history and ecological characteristics of the focal species (Hart and Sissenwine, 2009; Kaplan, 2009; White, 2009), with different taxa profiting to varying degrees and across variable timescales (Fox et al., 2012; Hays and Scott, 2013).

The fact that MPAs can effectively increase particular biological parameters of organisms under certain conditions (see discussion above) has been shown both in long-term numerical modeling approaches as well as short-term empirical studies (Gaines et al., 2010). Yet, these effectiveness studies have mostly focused on single or few harvested species (White et al., 2011). This stands in stark contrast to the demands of many policy instruments, such as the Natura 2000 program and the habitats directive of the European Union, which specifically call for a comprehensive evaluation of biological compartments occurring in MPAs, beyond the single species perspective (i.e., in a "holistic ecosystem perspective"). The effects of MPAs on ecosystem functioning and in particular on the relations of species interacting within food webs and the associated 
trophic cascades (i.e., the decline of some species in response to an increase in their competitors) has been largely overlooked in the evaluation of effectiveness of MPAs (Baskett et al., 2007). Investigating these ecological dependencies can, however, provide valuable insights in the response of whole biological communities to MPA establishment, beyond the mere change in a handful of biological metrics for a few species (White et al., 2011). Furthermore, an increase in the aforementioned metrics may not be the desirable and/or appropriate goal for a certain MPA, highlighting the need to define clear targets early on within the MPA establishment process (Pendleton et al., 2018).

\section{BIODIVERSITY CONSERVATION OR FISHERIES YIELD? MANAGING A SEA OF OBJECTIVES}

It is a common impression that the conservation and the (commercial) fisheries sector pursue drastically diverging interests and objectives. And indeed, establishing a marine protected area with fisheries restrictions in areas where fishing takes place creates-in most cases-some kind of conflict (Salmona and Verardi, 2001; Bennett and Dearden, 2014). However, research has shown that fishers perceive MPAs to not only entail costs (e.g., via displacement of fishers from fishing grounds), but also to result in benefits, like the increased possibility to catch large fish that "spill over" from the MPA into adjacent non-protected sites (Cinner et al., 2014).

From a conservation point of view, the rationale behind permanently restricting a fishery in a certain area in order to minimize the potential impact on the local biodiversity, is quite clear and larger MPAs that fully exclude any kind of anthropogenic activities (including fishing) are usually desired. Predicting the effect of MPAs on fisheries, however, is not as trivial and modeling studies often yield ambivalent results: under overfishing scenarios, a set of idealized MPAs with varying degrees of protection for commercial species were found to have the potential to increase fisheries in the long run. Under sustainable fishing scenarios, however, these same MPAs rather decreased the fishing yield (while still increasing the overall biomass of fish), as more area than necessary was off-limits to fishing (White et al., 2010, 2011). Moreover, the effect of an MPA on fisheries yield also depends on the way in which resource users shift their fishing effort after MPA implementation (Sanchirico and Wilen, 2001; Kellner et al., 2007). Taking all of these factors into account, trade-offs emerge between fisheries management goals and conservation objectives, influenced primarily by the number, size and spacing of MPAs with fisheries restrictions (Gaines et al., 2010). This apparent mismatch, however, may not be evident under all circumstances. For certain areas, the diverging objectives of the conservation and fisheries sector in terms of relative MPA coverage can in fact overlap, which may help to minimize trade-offs (Gaines et al., 2010) with the ultimate goal of manifesting the role of MPAs as an integral part of an effective ecosystem-based management of living marine resources (Grip and Blomqvist, 2020).
Within this "sea of objectives", the sustainable development goals (discussed above) specifically call for an approach simultaneously promoting environmental protection as well as economic growth (e.g., by restoring fish stocks or promoting sustainable tourism; Carter, 2007). Political agendas thus commonly aim to simultaneously promote conservation as well as sustainable fisheries targets (Humphreys and Clark, 2020). In the end, striving to reconcile both conservation and fisheries objectives, however, has the potential to achieve neither very effectively. That is especially so, unless stakeholders are an integral part of the MPA establishment and management process (Humphreys and Clark, 2020).

\section{MARINE PROTECTED AREAS AS COMPLEX SOCIAL-ECOLOGICAL SYSTEMS}

The establishment of MPAs quite prominently intertwines social, ecological and economic considerations (Pendleton et al., 2018; Humphreys and Clark, 2020). Behind (almost) every MPA stands a community of resource users and-by regulating their actionsmanagers aim to steer the ecological trajectories of defined seascapes. As new rules and regulations are set within an area, people are commonly forced to respond by adjusting their behavior. This alteration of actions notably takes place along a compliance gradient, i.e., some resource users will follow the set rules and others may decide to steer their way around them. This highlights the issue of compliance as well as enforcement of set rules and regulations. In the end, the efficacy and success of individual MPAs (as for most other management tools) is heavily influenced by the behavior and acceptance of people (Bennett and Dearden, 2014).

Different governance approaches and policy frameworks are distinctly equipped to solve the challenges associated with marine resource management and biodiversity conservation (McCay and Jones, 2011; Jones, 2012; Gaymer et al., 2014). In the MPA designation process, both bottom-up as well as top-down approaches are employed: While community-led (bottom-up) approaches are more commonly observed with smaller coastal MPAs that result in local impacts as well as benefits (Bartlett et al., 2010), central government-led (top-down) initiatives usually operate on larger scales and can-for example-facilitate the rapid establishment of extensive open-ocean MPAs (Toonen et al., 2013; Wilhelm et al., 2014) or large-scale national networks of MPAs (Buxton and Cochrane, 2015). While such systematic top-down approaches are well equipped to achieve trans-regional conservation targets, community-led approaches can be less costly and result in higher commitment as well as compliance by local stakeholders (Crawford et al., 2004). However, both of these extremes have also been criticized for invoking conservation and management failures (Qiu et al., 2009; Hind et al., 2010) and current MPA governance strategies thus increasingly try to incorporate the advantages of both approaches (Jones, 2001; Mills et al., 2010; Ban et al., 2011). Key lessons learned from several such cross-level initiatives around the globe include the need for early and ongoing engagement of all stakeholders as 
well as the creation and/or showcasing of incentives for local communities (from an economic perspective as well as in terms of two-way knowledge transfer; cf. Buxton and Cochrane, 2015 for an extensive documentation of the outcomes of an inclusive MPA process). Transparency throughout the entire MPA establishment process has been identified as a central component for successful MPA designation and participative processes as well as capacity building opportunities for stakeholders have been shown to increase community involvement (Gaymer et al., 2014; Buxton and Cochrane, 2015). In terms of MPA governance, the single most important lesson learned is that "one size does not fit all". The MPA designation process therefore always has to be adapted to local circumstances and should be well aligned with the context of the social-ecological system in which the MPA will be embedded (Gaymer et al., 2014).

Failing to recognize the disciplinary trinity (social, ecological and economic) of MPAs has led to a variety of conservation failures in the past (Cumming and Allen, 2017). Several studies have shown that some MPAs proven to be "ecological success stories", simultaneously represented "social failures" (e.g., Christie, 2004). One prominent reason for this phenomenon was found to be a lack of stakeholder engagement throughout the MPA process, from early conception to day-to-day management (Giakoumi et al., 2018). A recently published open letter ${ }^{5}$ (written in response to a draft working paper by Waldron et al., 2020, that analyzes the economic implications of the $30 \times 30$ MPA target and indicates that the financial benefits far outweigh the costs) sheds further light on this divergence: Ignoring the social aspects of conservation risks reinforcing the marginalization of vulnerable communities affected by the environmental protection measures.

Established MPAs that are poorly designed and/or managed, on the other hand, may provide a false sense of protection for stakeholders, while in reality being inapt to achieve set ecological targets (Agardy et al., 2011). It is therefore imperative to design MPAs in a way that is both ecologically as well as socially sustainable (Cumming and Allen, 2017; Bennett, 2018). In order to strive toward simultaneously promoting biodiversity conservation and safeguarding human livelihoods within the context of MPAs, learning how to properly integrate ecological as well as social considerations will be essential (yet certain trade-offs may be inevitable; Cumming et al., 2006; Mills et al., 2010; Guerrero et al., 2013; Bennett et al., 2021). The same reasoning has to be applied when it comes to evaluating the effectiveness of MPAs by addressing both biological as well as social considerations and integrating outcome metrics that span across disciplines. In this context, the social-ecological systems framework, defined by the intricate relationships of people and nature (Ostrom, 2009), can provide a holistic, interdisciplinary setting that paves the way for an effective, ecologically as well as socially sustainable marine protected area management. MPAs are after all a "social-ecological enterprise" (Chuenpagdee et al., 2013).

${ }^{5}$ https://openlettertowaldronetal.wordpress.com/ (last accessed on 05.04.2021)
The intricate links between society and nature quite clearly call for research methods that adequately reflect these interdependencies and feedbacks. Network analysis, a technique to depict and analyze relations and structures, holds great potential in this regard, as it enables an understanding of the direct and indirect processes characteristic for the resource management sector (Bascompte, 2009; Borgatti et al., 2009; Butts, 2009; Turnbull et al., 2018). To study complex processes at the human-nature interface and analyze superimposed effects of social and environmental mechanisms, the socalled social-ecological network analysis (SENA) is becoming an increasingly popular tool among interdisciplinary scholars (Sayles et al., 2019; Kluger et al., 2020). As an example, Haraldsson et al. (2020) used a SENA approach to study the effects of a future offshore wind farm to be placed off the coast of Northern France on both the ecosystem as well as the economic and social actors. Adopting and refining this approach within the context of MPAs may yield highly insightful outcomes by incorporating knowledge from various disciplines, and thus constitute a potent tool to facilitate the effective and interdisciplinary management of marine areas. Applying SENA in the planning and management of MPAs could allow decision-makers and managers to construct alternative scenarios and assess the effects of planned or undertaken strategies on the resources users and other units of the socialecological system in an MPA (Haraldsson et al., 2020). By using context-specific factors, this approach would furthermore allow to differentiate among economic activities that differ regarding their ecological impact, and their economic and cultural importance for the local human population (such as small-scale and industrial fisheries, Daw et al., 2009; Carvalho et al., 2011). This way, adverse socio-economic impacts on local communities by MPAs could be minimizedif not avoided-via the identification of the most vulnerable groups and their webs of relations in the MPA context. In fact, the strength of this approach lies in its adaptability to local circumstances, providing case-specific insights that can enable discussions between diverse stakeholders and subsequently guide the decision-making process from MPA inception to day-to-day management. In a nutshell, looking at linked networks of ocean and society is a promising avenue toward understanding MPAs as complex social-ecological systems and can aid in finding balance among social and economic aspects, as well as between conservation and fisheries interests.

\section{A FRAMEWORK FOR A SUCCESSFUL MPA ESTABLISHMENT PROCESS}

From a management perspective, the process of establishing a marine protected area incorporates distinct steps and phases (cf. Figure 2). The initial phase is characterized by strategic planning: In a first step, auspicious goals on the seascape scale have to be decided upon, ideally already incorporating a variety of stakeholder perspectives. Based on this prospect, sections of the ocean have to be identified that may provide suitable conditions 


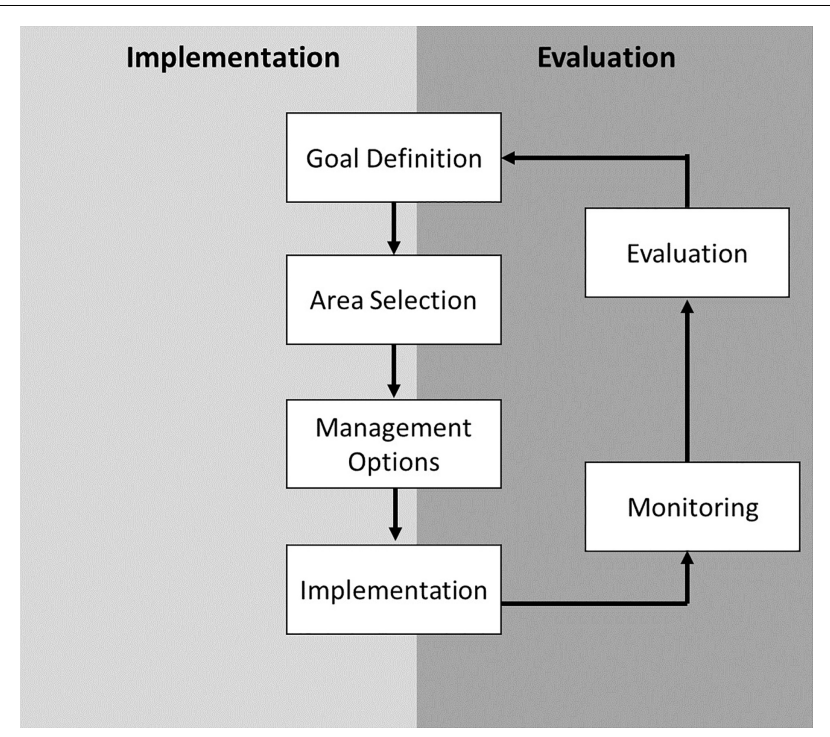

FIGURE 2 | Framework illustrating the marine protected area process from inception to evaluation. The implementation phase is followed by the evaluation phase, which feeds back into the former.

to achieve these objectives and a decision for specific sites has to be made (e.g., in a stakeholder participation process, see above). In pre-monitoring activities, the current ecological status as well as social and economic importance of the area should be assessed (with emphasis on the notion of variability as well as seasonal patterns). Based on the assessed local circumstances, the objectives should be further specified and operationalized via the use of indicators (e.g., Tunnicliffe et al., 2020). A clear picture of a desired future state (Bryson, 2018), including intermediate steps and milestones that pave the way toward reaching set targets, can be particularly beneficial. A thorough description of the current state of the social-ecological system with relevant links to applicable pressures finalizes this first step (Probst et al., 2016).

In a second step, an inventory of possible management options that would support the achievement of set objectives has to be created. In this context, balancing social as well as economic impacts of regulatory actions becomes imperative. Feasible management scenarios that can be (a) monitored and (b) enforced have to be agreed upon and a framework for noncompliance should be established. The final step within the MPA establishment process is the actual and effective implementation of management actions. A clear communication of the rules and regulations that are (or will be) in force as well as the rationale behind these management actions, can help to promote compliance. In parallel, controls of set regulations established upon a legal basis to issue sanctions have to come into force.

Following the successful implementation of the newly established MPA, the evaluation phase kicks in. Regular monitoring activities based on the pre-decided pressure and state indicators, assessed both inside as well as outside the MPA, are conducted and results compared against set targets on a rolling basis.

\section{MARINE PROTECTED AREAS IN THE BALTIC SEA-UNDERSTANDING THROUGH SIMPLICITY}

The Baltic Sea, a semi-enclosed brackish water body in Northern Europe, looks back on a long history of human use. It is characterized by a multitude of human-induced stressors ranging from fisheries, pollution and eutrophication to climate change (Diaz and Rosenberg, 2008; Reusch et al., 2018). In terms of salinity, it is a highly heterogeneous sea basin with conditions ranging from almost fully marine in the South-west to freshwater habitats in the North (Voipio, 1981). Due to its largely brackish conditions, which stresses both marine and freshwater species, as well as its geologically young age, the Baltic Sea constitutes a comparatively species poor environment with low functional diversity (Thulin, 2009; Elmgren and Hill, 2010). Due to its "simple" biological structure and multi-stressor environment coupled with a comparatively high data availability, it is argued that the Baltic Sea constitutes the perfect model region to implement and evaluate alternative marine management tools. In fact, it has been described as a "time machine" to investigate the operating principles of superimposed stressors within a future coastal ocean and a study area to test the efficacy of mitigation measures (Reusch et al., 2018).

The Baltic Sea, bordered by nine different countries (all but one forming part of the European Union), is one of the most managed seas in the world (Paasche et al., 2015; Reusch et al., 2018). The establishment of MPAs is one of the primary management tools employed to promote healthy Baltic Sea environments (Jonsson et al., 2020) and de facto MPAs have been established in this sea basin as early as 1932 (i.e., neartotal trawl ban in the Öresund; Anonymous, 1932). Even earlier than that, spatial protection measures for Baltic Sea fish spawning grounds (e.g., Strelasund) date back to the nineteenth century (World Wide Fund for Nature [WWF], 2017) and area closures as fisheries management tools are employed until this day (e.g., "Odra Bank closure" at the German-Polish border to protect juvenile flatfish, established in 2005).

One of the main international governing bodies that aim to conserve and sustainably manage the ecosystems of the Baltic Sea is the Baltic Marine Environment Protection Commission, also known as Helsinki Commission (in short "HELCOM"; HELCOM, 2009). Within the HELCOM framework, the first MPAs with the primary goal to protect habitats and species were designated in 1994 (HELCOM Recommendation 15/5 of 1994). Since then, these areas, known as Baltic Sea Protected Areas (BSPAs, more recently renamed "HELCOM MPAs"; HELCOM, 2013), have grown into an extensive network that spans the entire Baltic Sea. Other widely applied policy instruments are the EU habitats and birds directives (EC Birds Directive 1979, EC Habitats Directive 1992), which oblige EU member states to designate so-called "Natura 2000 sites", describing protected areas conserving particular habitats and species while simultaneously facilitating sustainable resource use within their boundaries. These Natura 2000 sites form part of a pan-European network of representative protected areas, consolidating and expanding the existing network of HELCOM MPAs. In fact, the 
majority of marine protected sites in the Baltic Sea are designated by both the HELCOM MPA and the EU Natura 2000 system, with an overlap of more than $90 \%$ (Jonsson et al., 2020).

The network of MPAs in the Baltic Sea reached the internationally aspired 10\% MPA coverage target already by 2010 and today, the Baltic Sea enjoys the highest protection (at least in terms of MPA coverage) of all European marine regions (European Environment Agency [EEA], 2015). Nonetheless, conservation experts highlight the uneven distribution of MPAs among sub-regions and a strong bias toward small sites in coastal waters (von Nordheim, 2018). In 2016, 13.5\% of the Baltic Sea (as designated by the HELCOM maritime area) was covered by MPAs, with a total number of 177 HELCOM MPAs and around one thousand Natura 2000 MPAs distributed throughout the sea basin (HELCOM, 2016). Despite the comparatively large extent of MPAs in the Baltic Sea, activities with a potentially high impact on marine ecosystems, such as construction activities (e.g., the "Fehmarnbelt crossing"; an immersed tunnel connecting Germany and Denmark to be built within the next 10 years) and resource extraction, are not strictly prohibited within these sites (HELCOM, 2013). Furthermore, potentially harmful fishing activities, such as bottom trawling, are commonly employed within MPAs (Berggren et al., 2020). Voices from the conservation sector thus highlight the fact that an effective conservation of marine ecosystems is currently not guaranteed for the Baltic Sea, even within sites designated as MPAs (von Nordheim, 2018).

The network of MPAs in the Baltic Sea is composed of MPAs that vary greatly in spatial extent, with a majority of the MPAs between 10 and $100 \mathrm{~km}^{2}$ in size (HELCOM, 2016; cf. Figure 3). Natura 2000 sites in the Baltic Sea are more numerous than HELCOM MPAs, however, they also tend to be generally smaller in size (Figure 3). It is worth mentioning that Natura 2000 sites designated through the two distinct EU directives, targeting birds on the one hand and habitats on the other, frequently overlap in geographic extent. While none of the MPAs in the Baltic Sea (i.e., neither HELCOM MPAs nor Natura 2000 sites) are classified as being "Fully/Highly Protected" by the MPAtlas", the majority of HELCOM MPAs already has a management plan (for at least parts of the site) in force (cf. Figure 4; von Nordheim, 2018; Jonsson et al., 2020). However, around one-third of HELCOM MPAs are only designated (i.e., do not have a management plan; Figure 4) and Natura 2000 sites lack management plans in the majority of cases.

The fact that the Baltic Sea has a long history of fishing activity while exhibiting an extensive network of MPAs, makes this sea basin particularly suitable for investigating the effectiveness of MPAs in achieving their targets. Besides the conservation value of MPAs in this sea basin, the question remains about their adequacy as fisheries management tools. While the management of commercial fish stocks is not their designated primary aim (i.e., the protection of habitats and species; see above), fish stocks can still profit from this conservation tool, for example, via the protection of essential habitats and safeguarding of certain ecosystem functions. The European Common Fisheries Policy (CFP) thus suggests to consider the implementation of fishing restrictions within MPAs in order

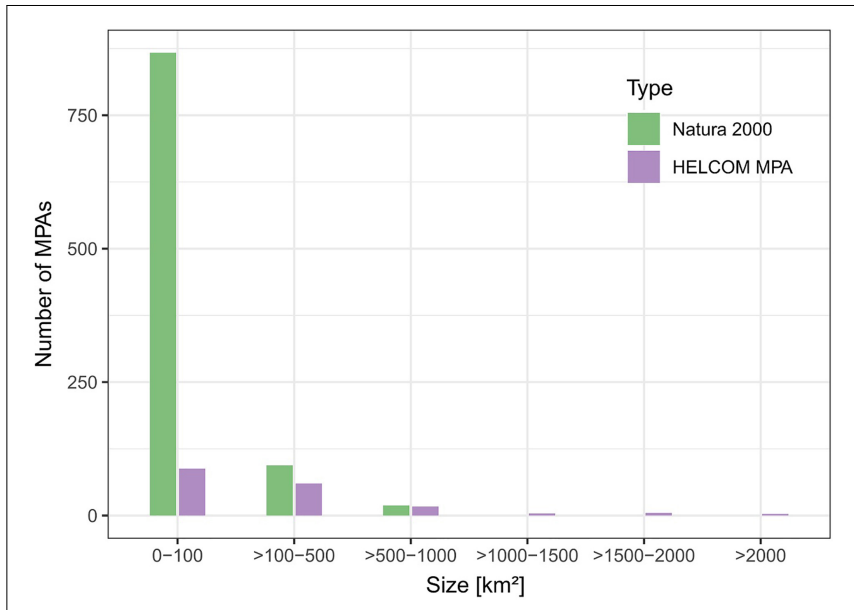

FIGURE 3 | Size frequency distribution of marine sections of HELCOM MPAs and Natura 2000 sites in the Baltic Sea. Sizes of marine sections of MPAs were calculated based on shapefiles obtained from https://maps.helcom.fi/ (HELCOM MPAs) and https://www.eea.europa.eu/data-and-maps/data/ natura-11/ (Natura 2000 sites) (both resources were last accessed on 05.04.2021).

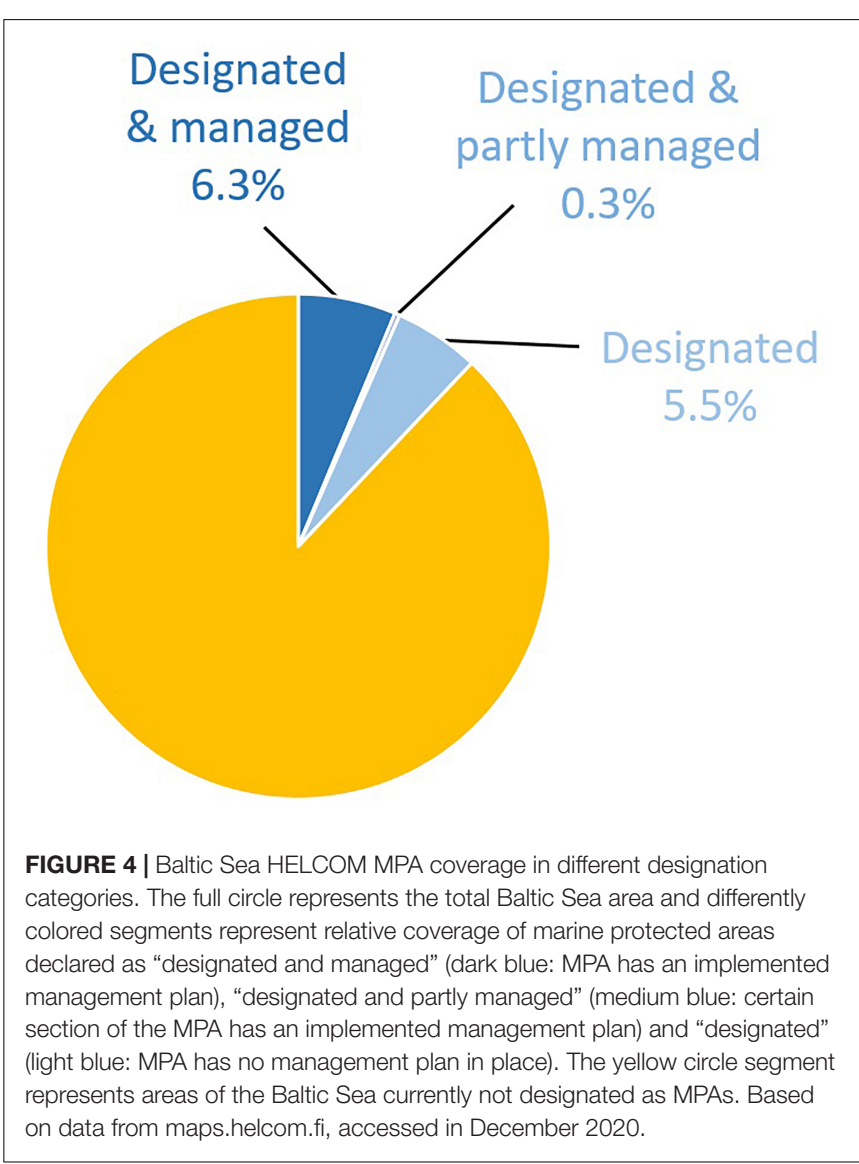

to contribute to the conservation of living aquatic resources and marine ecosystems (Common Fisheries Policy [CFP], 2013), while simultaneously aiming for an exploitation of fished populations at the level of maximum sustainable yield (MSY; i.e., 
maximizing catches while safeguarding future reproduction of fished populations, always following the precautionary principle; Langlet and Rayfuse, 2019). In this context, MPAs may convey an interesting role as an "insurance" or "buffer" for sudden and unexpected environmental or anthropogenic impacts and-placed in the right locations-may provide far-reaching benefits e.g., via the protection of vital spawning grounds (see above).

From a governance perspective, the notion of using MPAs to manage fisheries in Europe is particularly interesting: While marine conservation (and thus the establishment of MPAs) is a national concern, fisheries management is regulated by the CFP, centrally regulated by the European Union (Fock, 2010). In other words, if an EU member wants to restrict fishing activities within an MPA that lies within the waters under its own national jurisdiction, this EU member first has to consulate with EU countries that have fishing interests in the MPA to formulate a "joint recommendation" in a lengthy multi-step process (von Nordheim, 2018). In a second step, the EU Commission can then issue legally binding fishing regulations for the national MPA that all EU members have to abide to. Next to the prominent focus on the evaluation of biological measures, the CFP also suggests the consideration of economic as well as social criteria in the strive for fisheries sustainability (Common Fisheries Policy [CFP], 2013). In this respect, Yletyinen et al. (2018) investigated the driving factors and consequences of fishing strategy diversification among Swedish fishers within a first-of-its-kind social-ecological network study in a Baltic Sea fisheries context. Describing social-ecological networks via mental models, Schwermer et al. (2021) examined coupled human-nature interactions in the Western Baltic cod fishery incorporating the perspectives of multiple stakeholder groups. These approaches could be used and adapted to further incorporate the human dimension (see above) in the often mainly ecologically driven marine policies, such as Natura 2000 and the CFP, as well as the MPA process in general. Goti-Aralucea (2019) presents the-to our knowledge-first combined analysis of social and economic effects of an MPA in a Baltic Sea case study. This work thus starts to fill a research gap on the impacts of MPAs on fishers in this sea basin. While some studies on the economic or social aspects of spatial fisheries measures in the Baltic Sea have been published (e.g., Suuronen et al., 2010; Bastardie et al., 2020), the consideration of the social-ecologicaleconomic trinity in conjunction is still in its infancy. Such a combined analysis would greatly advance our understanding of the mechanisms and feedbacks intrinsic to the implementation of this management tool, prominently situated at the interface of ocean and society. After all, MPAs do not only advance national and international conservation agendas, but also manage peoples' interactions with the ocean.

MPAs in the Baltic Sea are-by virtue of the policy instruments employed for their designation-inherently static. Yet, their subjects of protection are often mobile (to varying degrees) and/or exhibit occurrence patterns modulated by climatic variability. Many of the species and habitats protected within MPAs may shift their range in response to climate change over the coming decades (Perry et al., 2005). Larval connectivity within existing MPA networks is also forecasted to change, with larval development duration largely coupled to sea temperature (O'Connor et al., 2007). This raises the question if MPAs designed to safeguard biodiversity and promote sustainable use of marine resources under today's conditions, will be able to do so in a future altered seascape.

\section{DISCUSSION AND LESSONS LEARNED}

Marine protected areas have-to a certain degree-emerged as panaceas in the ocean conservation arena (Young et al., 2018). Yet they exist in a variety of shapes and sizes as they are designated around the world using a broad range of legislative instruments. Following international conservation targets, their numbers have increased substantially in the last decades and this trend is very likely to continue in the future. In practice, MPAs are often situated at the crossroads between biodiversity conservation and fisheries management and are thus inherently characterized by diverging objectives and expectations by various stakeholders. This field of tension commonly demands contrasting sets of management actions, which call for compromises to be agreed upon. These tradeoffs, in turn, may create conflict among resource users and stakeholders at the local level, but also branch out to higher political spheres. Thus, we suggest the implementation of socialecological network analysis (SENA) as a flexible approach that accounts for the complex processes at the human-nature interface in a context-specific way. In order to acknowledge MPAs as economically, socially and politically viable options for managing the ocean, MPAs continuously have to prove that they are successful in achieving their goals. In scientific practice, however, assessing this effectiveness in a holistic way is not always an easy task and the important step of MPA evaluation is thus frequently skipped. Nevertheless, clear and measurable targets have to be decided upon early on within the MPA process, ideally involving interdisciplinary sets of indicators that span across the ecological, economic and social domain. These indicators are best conceived, field-tested and refined within research environments characterized by solid data availability. The Baltic Sea, described as one of the most protected oceanic realms in Europe, may constitute such a testing ground. While spatial protection measures in this sea basin can certainly be regarded as extensive, they may, however, currently not be as thorough as one would expect. The implementation of new spatial management measures (e.g., gear restrictions like trawl bans) within the MPA network of the Baltic Sea could constitute the ideal case study to validate their efficacy along environmental gradients. Solid longterm monitoring schemes within individual areas may provide valuable insights on MPA effectiveness in the light of a multistressor environment (e.g., characterized by eutrophication, climate change and fisheries). It is of no doubt that MPAs are here to stay for the foreseeable future. In this context, we have to learn how to most effectively use this management tool at the crossroads between biodiversity conservation and fisheries management. 


\section{AUTHOR CONTRIBUTIONS}

MK designed the theoretical framing and wrote the first draft of the manuscript. DO drafted the section "A Framework for a Successful MPA Establishment Process" and created Figure 2. $\mathrm{XE}, \mathrm{CD}$, and $\mathrm{DO}$ contributed to the conceptualization and revised the manuscript. All authors approved the submitted version.

\section{FUNDING}

This review was conducted within the DAM pilot mission "MGFOstsee" (Grant No. 03F0848B) funded by the German Federal Ministry of Education and Research. XE appreciates the funding

\section{REFERENCES}

Agardy, T., Di Sciara, G. N., and Christie, P. (2011). Mind the gap: addressing the shortcomings of marine protected areas through large scale marine spatial planning. Mar. Policy 35, 226-232. doi: 10.1016/j.marpol.2010. 10.006

Airamé, S., Dugan, J. E., Lafferty, K. D., Leslie, H., McArdle, D.A ., and Warner, R. R. (2003). Applying ecological criteria to marine reserve design: a case study from the California channel islands. Ecol. Appl. 13, 170-184. doi: 10.1890/105107612003013[0170:AECTMR]2.0.CO;2

Anonymous (1932). The Joint Commission with Denmark Concerning the Fisheries in Waters of Sweden and Denmark. Stockholm, 31 December 1932. In Swedish. Available online at: https://academic.oup.com/icesjms/article/70/6/ $1140 / 635387$

Ban, N. C., Adams, V. M., Almany, G. R., Ban, S., Cinner, J. E., McCook, L. J., et al. (2011). Designing, implementing and managing marine protected areas: emerging trends and opportunities for coral reef nations. J. Exp. Mar. Biol. Ecol. 408, 21-31. doi: 10.1016/j.jembe.2011.07.023

Bartlett, C. Y., Maltali, T., Petro, G., and Valentine, P. (2010). Policy implications of protected area discourse in the Pacific islands. Mar. Policy 34, 99-104. doi: 10.1016/j.marpol.2009.04.021

Bascompte, J. (2009). Disentangling the web of life. Science 325, 416-419. doi: 10.1126/science.1170749

Baskett, M. L. (2006). Prey size refugia and trophic cascades in marine reserves. Mar. Ecol. Prog. Ser. 328, 285-293. doi: 10.3354/meps328285

Baskett, M. L., Micheli, F., and Levin, S. A. (2007). Designing marine reserves for interacting species: insights from theory. Biol. Conserv. 137, 163-179. doi: 10.1016/j.biocon.2007.02.013

Bastardie, F., Danto, J., Rufener, M.-C., van Denderen, D., Eigaard, O. R., Dinesen, G. E., and Nielsen, J. R. (2020). Reducing fisheries impacts on the seafloor: a bio-economic evaluation of policy strategies for improving sustainability in the Baltic Sea. Fish. Res. 230:105681. doi: 10.1016/j.fishres.2020.105681

Beger, M., Jones, G. P., and Munday, P. L. (2003). Conservation of coral reef biodiversity: a comparison of reserve selection procedures for corals and fishes. Biol. Conserv. 111, 53-62. doi: 10.1016/S0006-3207(02)00249-5

Bennett, N. J. (2018). Navigating a just and inclusive path towards sustainable oceans. Mar. Policy 97, 139-146. doi: 10.1016/j.marpol.2018.06.001

Bennett, N. J., and Dearden, P. (2014). Why local people do not support conservation: community perceptions of marine protected area livelihood impacts, governance and management in Thailand. Mar. Policy 44, 107-116. doi: 10.1016/j.marpol.2013.08.017

Bennett, N. J., Blythe, J., White, C. S., and Campero, C. (2021). Blue growth and blue justice: ten risks and solutions for the ocean economy. Mar. Policy 125:104387. doi: 10.1016/j.marpol.2020.104387

Berggren, H. G., Liedekerke, V., de Thoreson, O., and Owen, S. (2020). A Sea Under Pressure: Bottom Trawling Impacts in the Baltic. Available online at https://wwwwwfbalticorg.cdn.triggerfish.cloud/uploads/2020/09/wwf-baltic- from the European Research Council project CLOCK-Climate Adaptation to Shifting Stocks (Grant Agreement 679812).

\section{ACKNOWLEDGMENTS}

We thank Fanny Barz for fruitful and highly insightful discussions on the human dimension of fisheries and the socialecological dynamics within MPAs and Christopher Zimmermann for providing profound insights into Baltic Sea fisheries. We furthermore thank Linda Köhler for sharpening our view on the importance of MPAs for red-listed species and Remo Wiechert for technical support. We appreciate the funding of the publishing costs via the state of Bremen and the dedication of everyone involved in ICYMARE.

a-sea-under-pressure_impacts-of-bottom-trawling-2020.pdf (accessed April 05, 2021).

Borgatti, S. P., Mehra, A., Brass, D. J., and Labianca, G. (2009). Network analysis in the social sciences. Science 323, 892-895. doi: 10.1126/science.11 65821

Botsford, L. W., Hastings, A., and Gaines, S. D. (2001). Dependence of sustainability on the configuration of marine reserves and larval dispersal distance. Ecol. Lett. 4, 144-150. doi: 10.1046/j.1461-0248.2001. 00208.x

Bryson, J. M. (2018). Strategic Planning for Public and Nonprofit Organizations. A Guide to Strengthening and Sustaining Organizational Achievement. Fifth edn. Hoboken, NJ: John Wiley \& Sons Inc.

Butchart, S. H. M., Walpole, M., Collen, B., van Strien, A., Scharlemann, J.P.W., Almond, R.E.A., et al. (2010). Global biodiversity: indicators of recent declines. Science 328, 1164-1168. doi: 10.1126/science.1187512

Butts, C. T. (2009). Revisiting the foundations of network analysis. Science 325, 414-416. doi: 10.1126/science.1171022

Buxton, C. D., and Cochrane, P. (2015). Commonwealth Marine Reserves Review: Report of the Bioregional Advisory Panel. Canberra: Department of the Environment, 341.

Buxton, C. D., Barrett, N. S., Haddon, M., Gardner, C., and Edgar, G. J. (2006). Evaluating the Effectiveness of Marine Protected Areas as a Fisheries Management Tool. Fisheries Research Development Corporation Final Report 1999/162. Canberra: Fisheries Research Development Corporation, 384.

Buxton, C. D., Hartmann, K., Kearney, R., and Gardner, C. (2014). When is spillover from marine reserves likely to benefit fisheries? PLoS One 9:e107032. doi: 10.1371/journal.pone.0107032

Carter, J. (2007). Spatial planning, water and the water framework directive: insights from theory and practice. Geogr. J. 173, 330-342. doi: 10.1111/j.14754959.2007.00257.x

Carvalho, N., Edwards-Jones, G., and Isidro, E. (2011). Defining scale in fisheries: small versus large-scale fishing operations in the Azores. Fish. Res. 109, 360-369. doi: 10.1016/j.fishres.2011.03.006

Caveen, A., Polunin, N., Gray, T., and Stead, S. M. (2015). The Controversy over Marine Protected Areas. Cham: Springer International Publishing.

CBD (2010). Decisions Adopted by the Conference of the Parties to the Convention on Biological Diversity at its 10th Meeting, X/2. Available online at: https://www. cbd.int/decision/cop/?id=12268 (accessed April 05, 2021).

Christie, P. (2004). Marine protected areas as biological successes and social failures in Southeast Asia. Am. Fish. Soc. Symp. 42:155-164.

Chuenpagdee, R., Pascual-Fernández, J. J., Szeliánszky, E., Luis Alegret, J., Fraga, J., and Jentoft, S. (2013). Marine protected areas: re-thinking their inception. Mar. Policy 39, 234-240. doi: 10.1016/j.marpol.2012.10.016

Cinner, J. E., Daw, T., Huchery, C., Thoya, P., Wamukota, A., Cedras, M., et al. (2014). Winners and losers in marine conservation: fishers' displacement and livelihood benefits from marine reserves. Soc. Nat. Resourc. 27, 994-1005. doi: $10.1080 / 08941920.2014 .918229$ 
Claudet, J., Osenberg, C. W., Benedetti-Cecchi, L., Domenici, P., García-Charton, J.-A., Pérez-Ruzafa, A., et al. (2008). Marine reserves: size and age do matter. Ecol. Lett. 11, 481-489. doi: 10.1111/j.1461-0248.2008.01166.x

Claudet, J., Osenberg, C. W., Domenici, P., Badalamenti, F., Milazzo, M., Falcón, J. M., et al. (2010). Marine reserves: fish life history and ecological traits matter. Ecol. Appl. 20, 830-839. doi: 10.1890/08-2131.1

Common Fisheries Policy [CFP] (2013). Regulation (EU) No 1380/2013 of the European Parliament and of the Council of 11 December 2013 on the Common Fisheries Policy, amending Council Regulations (EC) No 1954/2003 and (EC) No 1224/2009 and repealing Council Regulations (EC) No 2371/2002 and (EC) No 639/2004 and Council Decision 2004/585/EC. Brussels: Common Fisheries Policy.

Cormier-Salem, M.-C. (2014). Participatory Governance of Marine Protected Areas: A Political Challenge, an Ethical Imperative, Different Trajectories. France: Surveys and perspectives integrating environment and society.

Crawford, B., Siahainenia, A., Rotinsulu, C., and Sukmara A. (2004). Compliance and enforcement of community-based coastal resource management regulations in North Sulawesi, Indonesia. Coast. Manag. 32, 39-50. doi: 10.1080/08920750490247481

Crowder, L. B., Hazen, E. L., Avissar, N., Bjorkland, R., Latanich, C., and Ogburn, M. B. (2008). The impacts of fisheries on marine ecosystems and the transition to ecosystem-based management. Annu. Rev. Ecol. Evol. Syst. 39, 259-278. doi: 10.1146/annurev.ecolsys.39.110707.173406

Cumming, G. S., and Allen, C. R. (2017). Protected areas as social-ecological systems: perspectives from resilience and social-ecological systems theory. Ecol. Appl. 27, 1709-1717. doi: 10.1002/eap.1584

Cumming, G. S., Cumming, D. H., and Redman, C. L. (2006). Scale mismatches in social-ecological systems: causes, consequences, and solutions. Ecol. Soc. 11:14.

Daw, T., Adger, W. N., Brown, K., and Badjeck, M. C. (2009). Climate change and capture fisheries: potential impacts, adaptation and mitigation. In: Cochrane, $\mathrm{K}$, De Young, C, Soto, D, and Bahri, T. (eds.) Climate Change Implications for Fisheries and Aquaculture: Overview of Current Scientific Knowledge. FAO Fisheries and Aquaculture Technical Paper. No. 530. Rome: FAO, 107-150.

Day, J., Dudley, N., Hockings, M., Holmes, G., Laffoley, D. D. A., Stolton, S., et al. (2012). Guidelines for Applying the IUCN Protected Area Management Categories to Marine Protected Areas. Gland: IUCN.

Devillers, R., Lemieux, C.J., Gray, P. A., and Claudet, J. (2019). Canada's uncharted conservation approach. Science 364:1243. doi: 10.1126/science.aax9060

Diaz, R. J., and Rosenberg, R. (2008). Spreading dead zones and consequences for marine ecosystems. Science 321, 926-929. doi: 10.1126/science.1156401

Duarte, C. M., Agusti, S., Barbier, E., Britten, G. L., Castilla, J. C., Gattuso, J.-P., et al. (2020). Rebuilding marine life. Nature 580, 39-51. doi: 10.1038/s41586020-2146-7

Dyck, A. J., and Sumaila, U. R. (2010). Economic impact of ocean fish populations in the global fishery. J. Bioecon. 12, 227-243. doi: 10.1007/s10818-010-9088-3

Edgar, G. J., Stuart-Smith, R. D., Willis, T. J., Kininmonth, S., Baker, S. C., Banks, S., et al. (2014). Global conservation outcomes depend on marine protected areas with five key features. Nature 506, 216-220. doi: 10.1038/nature 13022

Elmgren, R., and Hill, C. (2010). Ecosystem function at low biodiversity - the Baltic example. In R. F. G. Ormond, J. D. Gage, M. V. Angel, (eds.). Marine Biodiversity. Cambridge: Cambridge University Press, 319-336.

European Environment Agency [EEA] (2015). Spatial Analysis of Marine Protected Area Networks in Europe's Seas. Technical Report No 17/2015. Copenhagen: European Environment Agency.

FAO (2020a). FAO Yearbook. Fishery and Aquaculture Statistics 2018. Rome: FAO.

FAO (2020b). The State of World Fisheries and Aquaculture. Sustainability in Action. Rome: FAO.

Fock, H. (2010). Natura 2000 and the Common Fisheries Policy. IP/B/PECH/IC/2009-88. Brussels: European Parliament.

Fox, H. E., Soltanoff, C. S., Mascia, M. B., Haisfield, K. M., Lombana, A. V., Pyke, C. R., et al. (2012). Explaining global patterns and trends in marine protected area (MPA) development. Mar. Policy 36, 1131-1138. doi: 10.1016/j.marpol. 2012.02.007

Gabrielsen, P., and Bosch, P. (2003). Environmental Indicators: Typology and Use in Reporting. EEA internal Working Paper, 20. Copenhagen: European Environment Agency.
Gaines, S. D., White, C., Carr, M. H., and Palumbi, S. R. (2010). Designing marine reserve networks for both conservation and fisheries management. Proc. Natl. Acad. Sci. U.S.A. 107, 18286-18293. doi: 10.1073/pnas.0906473107

Gaymer, C. F., Stadel, A. V., Ban, N. C., Cárcamo, P. F., Ierna, J., and Lieberknecht, L. M. (2014). Merging top-down and bottom-up approaches in marine protected areas planning: experiences from around the globe. Aquat. Conserv. Mar. Freshw. Ecosyst. 24, 128-144. doi: 10.1002/aqc.2508

Giakoumi, S., McGowan, J., Mills, M., Beger, M., Bustamante, R. H., Charles, A., et al. (2018). Revisiting "Success" and "Failure" of marine protected areas: a conservation scientist perspective. Front. Mar. Sci. 5:223. doi: 10.3389/fmars. 2018.00223

Gladstone, W. (2007). Requirements for marine protected areas to conserve the biodiversity of rocky reef fishes. Aquat. Conserv. Mar. Freshw. Ecosyst. 17, 71-87. doi: 10.1002/aqc.759

Goti-Aralucea, L. (2019). Assessing the social and economic impact of small scale fisheries management measures in a marine protected area with limited data. Mar. Policy 101, 246-256. doi: 10.1016/j.marpol.2017.10.039

Grip, K., and Blomqvist, S. (2020). Marine nature conservation and conflicts with fisheries. Ambio 49, 1328-1340. doi: 10.1007/s13280-019-01279-7

Guerrero, A. M., McAllister, R. R. J., Corcoran, J., and Wilson, K. A. (2013). Scale mismatches, conservation planning, and the value of social-network analyses. Conserv. Biol. 27, 35-44. doi: 10.1111/j.1523-1739.2012.01964.x

Halpern, B. S., and Warner, R. R. (2002). Marine reserves have rapid and lasting effects. Ecol. Lett. 5, 361-366. doi: 10.1046/j.1461-0248.2002.00326.x

Halpern, B. S., Gaines, S. D., and Warner, R. R. (2004). Confounding effects of the export of production and the displacement of fishing effort from marine reserves. Ecol. Appl. 14, 1248-1256. doi: 10.1890/03-5136

Halpern, B. S., Lester, S. E., and McLeod, K. L. (2010). Placing marine protected areas onto the ecosystem-based management seascape. Proc. Natl. Acad. Sci. U.S.A. 107, 18312-18317. doi: 10.1073/pnas.0908503107

Halpern, B. S., Longo, C., Hardy, D., McLeod, K. L., Samhouri, J. F., Katona, S. K., et al. (2012). An index to assess the health and benefits of the global ocean. Nature 488, 615-620. doi: 10.1038/nature11397

Haraldsson, M., Raoux, A., Riera, F., Hay, J., Dambacher, J.M., and Niquil, N. (2020). How to model social-ecological systems? - a case study on the effects of a future offshore wind farm on the local society and ecosystem, and whether social compensation matters. Mar. Policy 119:104031. doi: 10.1016/j.marpol. 2020.104031

Harasti, D., Williams, J., Mitchell, E., Lindfield, S., and Jordan, A. (2018). Increase in relative abundance and size of snapper chrysophrys auratus within partiallyprotected and no-take areas in a temperate marine protected area. Front. Mar. Sci. 5:208. doi: 10.3389/fmars.2018.00208

Hart, D. R. (2006). When do marine reserves increase fishery yield? Can. J. Fish. Aquat. Sci. 63, 1445-1449. doi: 10.1139/f06-071

Hart, D. R., and Sissenwine, M. P. (2009). Marine reserve effects on fishery profits: a comment on White et al. (2008). Ecol. Lett. 12, E9-E11. doi: 10.1111/j.14610248.2008.01272.x

Hays, G. C., and Scott, R. (2013). Global patterns for upper ceilings on migration distance in sea turtles and comparisons with fish, birds and mammals. Funct. Ecol. 27, 748-756. doi: 10.1111/1365-2435.12073

HELCOM (2009). Biodiversity in the Baltic Sea - An Integrated Thematic Assessment on Biodiversity and Nature Conservation in the Baltic Sea. Baltic Sea Environmental Proceedings No. 116B. Helsinki: HELCOM.

HELCOM (2013). HELCOM PROTECT - Overview of the Status of the Network of Baltic Sea Marine Protected Areas, 31 pp. Helsinki: HELCOM.

HELCOM (2016). Ecological Coherence Assessment of the MPA Network in the Baltic Sea. Baltic Sea Environmental Proceedings No. 148. Helsinki: HELCOM.

Hilborn, R. (2016). Policy: marine biodiversity needs more than protection. Nature 535, 224-226. doi: 10.1038/535224a

Hilborn, R. (2018). Are MPAs effective? ICES J. Mar. Sci. 75, 1160-1162. doi: 10.1093/icesjms/fsx068

Hilborn, R., Stokes, K., Maguire, J.-J., Smith, T., Botsford, L. W., Mangel, M., et al. (2004). When can marine reserves improve fisheries management? Ocean Coast. Manag. 47, 197-205. doi: 10.1016/j.ocecoaman.2004. 04.001

Hind, E. J., Hiponia, M. C., and Gray, T. S. (2010). From community-based to centralised national management-A wrong turning for the governance of 
the marine protected area in Apo Island, Philippines? Mar. Policy 34, 54-62. doi: 10.1016/j.marpol.2009.04.011

Horta e Costa, B., Claudet, J., Franco, G., Erzini, K., Caro, A., and Gonçalves, E. J. (2016). A regulation-based classification system for Marine Protected Areas (MPAs). Mar. Policy 72, 192-198. doi: 10.1016/j.marpol.2016.06.021

Humphreys, J., and Clark, R. W. E. (2020). “A critical history of marine protected areas," in Marine Protected Areas, eds J. Humphreys and R.W.E. Clark (Amsterdam: Elsevier), 1-12.

Jackson, J. B., Kirby, M. X., Berger, W. H., Bjorndal, K. A., Botsford, L. W., Bourque, B. J., et al. (2001). Historical overfishing and the recent collapse of coastal ecosystems. Science 293, 629-637. doi: 10.1126/science.1059199

Jennings, S., Kaiser, M. J. (1998). The effects of fishing on marine ecosystems. $A d v$. Mar. Biol. 34, 201-352.

Jones, P. J. S. (2001). Marine protected area strategies: issues, divergences and the search for middle ground. Rev. Fish. Biol. Fish. 11, 197-216. doi: 10.1023/A\% 3A1020327007975

Jones, P. J. S. (2009). Equity, justice and power issues raised by no-take marine protected area proposals. Mar. Policy 33, 759-765. doi: 10.1016/j.marpol.2009. 02.009

Jones, P.J.S. (2012). Marine protected areas in the UK: challenges in combining topdown and bottom-up approaches to governance. Environ. Conserv. 39, 248-258. doi: 10.1017/S0376892912000136

Jonsson, P. R., Moksnes, P.-O., Corell, H., Bonsdorff, E., and Nilsson Jacobi, M. (2020). Ecological coherence of marine protected areas: new tools applied to the Baltic Sea network. Aquat. Conserv. Mar. Freshw. Ecosyst. 30, 743-760. doi: $10.1002 /$ aqc. 3286

Kaiser, M. J. (2005). Are marine protected areas a red herring or fisheries panacea? Can. J. Fish. Aquat. Sci. 62, 1194-1199. doi: 10.1139/f05-056

Kaplan, D. M. (2009). Fish life histories and marine protected areas: an odd couple? Mar. Ecol. Prog. Ser. 377, 213-225. doi: 10.3354/meps07825

Kati, V., Hovardas, T., Dieterich, M., Ibisch, P. L., Mihok, B., and Selva, N. (2014). The challenge of implementing the European network of protected areas Natura 2000. Conserv. Biol. 29, 260-270. doi: 10.1111/cobi.12366

Kearney, R., Buxton, C. D., and Farebrother, G. (2012). Australia's no-take marine protected areas: appropriate conservation or inappropriate management of fishing? Mar. Policy 36, 1064-1071. doi: 10.1016/j.marpol.2012.02.024

Kelleher, G. (1999). Guidelines for Marine Protected Areas. Gland: IUCN.

Kellner, J. B., Tetreault, I., Gaines, S. D., and Nisbet, R. M. (2007). Fishing the line near marine reserves in single and multispecies fisheries. Ecol. Appl. 17, 1039-1054. doi: 10.1890/05-1845

Kluger, L. C., Gorris, P., Kochalski, S., Mueller, M. S., and Romagnoni, G. (2020). Studying human-nature relationships through a network lens: a systematic review. People Nat. 2, 1100-1116. doi: 10.1002/pan3.10136

Langlet, D., and Rayfuse, R. G. (Eds.) (2019). The Ecosystem Approach in Ocean Planning and goverNance. Perspectives from Europe and Beyond. Leiden: Brill Nijhoff (Publications on ocean development, 87).

Lester, S. E., Halpern, B. S., Grorud-Colvert, K., Lubchenco, J., Ruttenberg, B. I., Gaines, S. D., et al. (2009). Biological effects within no-take marine reserves: a global synthesis. Mar. Ecol. Prog. Ser. 384, 33-46. doi: 10.3354/meps 08029

Lotze, H. K., Lenihan, H. S., Bourque, B.J., Bradbury, R. H., Cooke, R. G., Kay, M. C., et al. (2006). Depletion, degradation, and recovery potential of estuaries and coastal seas. Science 312, 1806-1809. doi: 10.1126/science.112 8035

Lubchenco, J., and Grorud-Colvert, K. (2015). Making waves: the science and politics of ocean protection. Science 350, 382-383. doi: 10.1126/science.aad5443

Lubchenco, J., Palumbi, S. R., Gaines, S. D., and Andelman, S. (2003). Plugging a hole in the ocean: the emerging science of marine reserves. Ecol. Appl. 13, 3-7. doi: 10.1890/1051-07612003013[0003:PAHITO]2.0.CO;2.

McCay, B. J., and Jones, P.J.S. (2011). Marine protected areas and the governance of marine ecosystems and fisheries. Conserv. Biol. 25, 1130-1133. doi: 10.1111/ j.1523-1739.2011.01771.x

Mills, M., Pressey, R. L., Weeks, R., Foale, S., and Ban, N. C. (2010). A mismatch of scales: challenges in planning for implementation of marine protected areas in the Coral Triangle. Conserv. Lett. 3, 291-303. doi: 10.1111/j.1755-263X.2010. 00134.x

O’Connor, M. I., Bruno, J. F., Gaines, S. D., Halpern, B. S., Lester, S. E., Kinlan, B. P., et al. (2007). Temperature control of larval dispersal and the implications for marine ecology, evolution, and conservation. Proc. Natl. Acad. Sci. U.S.A. 104, 1266-1271. doi: 10.1073/pnas.0603422104

Oesterwind, D., Rau, A., and Zaiko, A. (2016). Drivers and pressures - untangling the terms commonly used in marine science and policy. J. Environ. Manag. 181, 8-15. doi: 10.1016/j.jenvman.2016.05.058

Ojea, E., Pearlman, I., Gaines, S. D., and Lester, S. E. (2017). Fisheries regulatory regimes and resilience to climate change. Ambio 46, 399-412. doi: 10.1007/ s13280-016-0850-1

O’Leary, B. C., Winther-Janson, M., Bainbridge, J. M., Aitken, J., Hawkins, J. P., and Roberts, C. M. (2016). Effective coverage targets for ocean protection. Conserv. Lett. 9, 398-404. doi: 10.1111/conl.12247

Ostrom, E. (2009). A general framework for analyzing sustainability of socialecological systems. Science 325, 419-422. doi: 10.1126/science.1172133

Paasche, Ø., Österblom, H., Neuenfeldt, S., Onsdorff, E., Brander, K., Conley, D. J., et al. (2015). Connecting the seas of norden. Nat. Clim. Chang. 5, 89-92. doi: $10.1038 /$ nclimate 2471

Pendleton, L. H., Ahmadia, G. N., Browman, H. I., Thurstan, R. H., Kaplan, D. M., and Bartolino, V. (2018). Debating the effectiveness of marine protected areas. ICES J. Mar. Sci. 1156-1159. doi: 10.1093/icesjms/fsx154

Perry, A. L., Low, P. J., Ellis, J. R., and Reynolds, J. D. (2005). Climate change and distribution shifts in marine fishes. Science 308, 1912-1915. doi: 10.1126/ science.1111322

Probst, W.N., Rau, A., and Oesterwind, D. (2016). A proposal for restructuring descriptor 3 of the Marine Strategy Framework Directive (MSFD). Mar. Policy 74, 128-135. doi: 10.1016/j.marpol.2016.09.026

Qiu, W., Wang, B., Jones, P. J. S., and Axmacher, J. C. (2009). Challenges in developing China's marine protected area system. Mar. Policy 33, 599-605. doi: 10.1016/j.marpol.2008.12.005

Ramirez-Llodra, E., Tyler, P. A., Baker, M. C., Bergstad, O. A., Clark, M. R., Escobar, E., et al. (2011). Man and the last great wilderness: human impact on the deep sea. PLoS One 6:e22588. doi: 10.1371/journal.pone.0022588

Rees, S. E., Pittman, S.J., Foster, N., Langmead, O., Griffiths, C., Fletcher, S., et al. (2018). Bridging the divide: social-ecological coherence in marine protected area network design. Aquat. Conserv. Mar. Freshw. Ecosyst. 28, 754-763. doi: 10.1002/aqc. 2885

Reuchlin-Hugenholtz, E., and McKenzie, E. (2015). Marine Protected Areas: Smart Investments in Ocean Health. Gland: WWF.

Reusch, T. B. H., Dierking, J., Andersson, H. C., Bonsdorff, E., Carstensen, J., Casini, M., et al. (2018). The Baltic Sea as a time machine for the future coastal ocean. Sci. Adv. 4:eaar8195. doi: 10.1126/sciadv.aar8195

Rife, A. N., Erisman, B., Sanchez, A., and Aburto-Oropeza, O. (2012). When good intentions are not enough ...insights on networks of "paper park" marine protected areas. Conserv. Lett. 6, 200-212. doi: 10.1111/j.1755-263X. 2012.00303.x

Russ, G. R., Alcala, A. C., Maypa, A. P., Calumpong, H. P., and White, A. T. (2004). Marine reserve benefits local fisheries. Ecol. Appl. 14, 597-606. doi: 10.1890/03-5076

Russ, G. R., Cheal, A. J., Dolman, A. M., Emslie, M. J., Evans, R. D., Miller, I., et al. (2008). Rapid increase in fish numbers follows creation of world's largest marine reserve network. Curr. Biol. 18, R514-R515. doi: 10.1016/j.cub.2008.04.016

Sala, E., Aburto-Oropeza, O., Paredes, G., Parra, I., Barrera, J. C., and Dayton, P. K. (2002). A general model for designing networks of marine reserves. Science 298, 1991-1993. doi: 10.1126/science.1075284

Sala, E., Lubchenco, J., Grorud-Colvert, K., Novelli, C., Roberts, C., and Sumaila, U. R. (2018). Assessing real progress towards effective ocean protection. Mar. Policy 91, 11-13. doi: 10.1016/j.marpol.2018.02.004

Sala, E., Mayorga, J., Bradley, D., Cabral, R. B., Atwood, T. B., Auber, A., et al. (2021). Protecting the global ocean for biodiversity, food and climate. Nature 592, 397-402. doi: 10.1038/s41586-021-03371-z

Salmona, P., and Verardi, D. (2001). The marine protected area of Portofino, Italy: a difficult balance. Ocean Coast. Manag. 44, 39-60. doi: 10.1016/S0964-5691(00) 00084-3

Sanchirico, J. N., and Wilen, J. E. (2001). A bioeconomic model of marine reserve creation. J. Environ. Econ. Manag. 42, 257-276. doi: 10.1006/jeem.2000.1162

Sayles, J. S., Mancilla Garcia, M., Hamilton, M., Alexander, S. M., Baggio, J. A., Fischer, A. P., et al. (2019). Social-ecological network analysis for sustainability sciences: a systematic review and innovative research agenda for the future. Environ. Res. Lett. 14:93003. doi: 10.1088/1748-9326/ab2619 
Schwermer, H., Aminpour, P., Reza, C., Funk, S., Möllmann, C., and Gray, S. (2021). Modeling and understanding social-ecological knowledge diversity. Conserv. Sci. Pract. e396. doi: 10.1111/csp2.396

Sciberras, M., Jenkins, S. R., Kaiser, M. J., Hawkins, S. J., and Pullin, A. S. (2013). Evaluating the biological effectiveness of fully and partially protected marine areas. Environ. Evid. 2:4. doi: 10.1186/2047-2382-2-4

Sowman, M., and Sunde, J. (2018). Social impacts of marine protected areas in South Africa on coastal fishing communities. Ocean Coast. Manag. 157, 168-179. doi: 10.1016/j.ocecoaman.2018.02.013

Sumaila, U. R., Cheung, W., Dyck, A., Gueye, K., Huang, L., Lam, V., et al. (2012). Benefits of rebuilding global marine fisheries outweigh costs. PLoS One 7:e40542. doi: 10.1371/journal.pone.0040542

Suuronen, P., Jounela, P., and Tschernij, V. (2010). Fishermen responses on marine protected areas in the Baltic cod fishery. Mar. Policy 34, 237-243. doi: 10.1016/ j.marpol.2009.07.001

Teh, L. C. L., and Sumaila, U.R. (2011). Contribution of marine fisheries to worldwide employment. Fish Fish. 14, 77-88. doi: 10.1111/j.1467-2979.2011. 00450.x

Thulin, J. (2009). "The recovery and sustainablity of the balti sea large marine ecosystem," in Sustaining the World's Large Marine Ecosystems, eds K. Sherman, M.-C. Aquarone, S. Adams (IUCN: Gland), 63.

Toonen, R. J., Wilhelm, T. A., Maxwell, S. M., Wagner, D., Bowen, B. W., Sheppard, C. R. C., et al. (2013). One size does not fit all: the emerging frontier in largescale marine conservation. Mar. Pollut. Bull. 77, 7-10. doi: 10.1016/j.marpolbul. 2013.10.039

Tunnicliffe, V., Metaxas, A., Le Tran, J., Ramirez-Llodra, E., and Levin, L. A. (2020). Strategic environmental goals and objectives: setting the basis for environmental regulation of deep seabed mining. Mar. Policy 114:103347. doi: 10.1016/j.marpol.2018.11.010

Turnbull, L., Hütt, M.-T., Ioannides, A. A., Kininmonth, S., Poeppl, R., Tockner, K., et al. (2018). Connectivity and complex systems: learning from a multidisciplinary perspective. Appl. Netw. Sci. 3:11. doi: 10.1007/s41109-0180067-2

Voipio, A. (Ed.) (1981). The Baltic Sea. New York, NY: Elsevier.

von Nordheim, H. (2018). Marine Protected Areas: Global Framework, Regional MPA Networks and a National Example. Cham: Springer International Publishing.

Waldron, A., Adams, V., Allan, J., Arnell, A., Asner, G., Atkinson, S., et al. (2020). Protecting 30\% of the Planet for Nature: Costs, Benefits and Economic Implications. Washington, DC: Campaign for Nature.

White, C. (2009). Density dependence and the economic efficacy of marine reserves. Theor. Ecol. 2, 127-138. doi: 10.1007/s12080-0090039-3

White, C., and Kendall, B. E. (2007). A reassessment of equivalence in yield from marine reserves and traditional fisheries managament. Oikos 116, 2039-2043. doi: 10.1111/j.2007.0030-1299.16167.x
White, J. W., Botsford, L. W., Baskett, M. L., Barnett, L. A. K., Barr, R. J., and Hastings, A. (2011). Linking models with monitoring data for assessing performance of no-take marine reserves. Front. Ecol. Environ. 9, 390-399. doi: $10.1890 / 100138$

White, J. W., Botsford, L. W., Moffitt, E. A., and Fischer, D. T. (2010). Decision analysis for designing marine protected areas for multiple species with uncertain fishery status. Ecol. Appl. 20, 1523-1541. doi: 10.1890/090962.1

Wilhelm, T. A., Sheppard, C. R. C., Sheppard, A. L. S., Gaymer, C. F., Parks, J., Wagner, D., et al. (2014). Large marine protected areas - advantages and challenges of going big. Aquat. Conserv. Mar. Freshw. Ecosyst. 24, 24-30. doi: $10.1002 / \mathrm{aqc} .2499$.

Wilson, E. O. (2016). Half-Earth: Our Planet's Fight for Life. New York, NY, Liveright Publishing Corporation.

Woodcock, P., O’Leary, B. C., Kaiser, M. J., and Pullin, A. S. (2017). Your evidence or mine? Systematic evaluation of reviews of marine protected area effectiveness. Fish Fish. 18, 668-681. doi: 10.1111/faf.12196

World Wide Fund for Nature [WWF] (2017). Angeln und Naturschutz im Greifswalder Bodden und Strelasund. Gland: WWF.

Worldbank (2012). Hidden Harvest: The Global Contribution of Capture Fisheries. Washington, DC: Worldbank.

Worm, B., Barbier, E. B., Beaumont, N., Duffy, J. E., Folke, C., Halpern, B. S., et al. (2006). Impacts of biodiversity loss on ocean ecosystem services. Science 314, 787-790. doi: 10.1126/science.1132294

Worm, B., Hilborn, R., Baum, J. K., Branch, T. A., Collie, J. S., Costello, C., et al. (2009). Rebuilding global fisheries. Science 325, 578-585. doi: 10.1126/science. 1173146

WPC (2014). Report from World Parks Congress in Sydney, Australia. Gland: IUCN. Yletyinen, J., Hentati-Sundberg, J., Blenckner, T., and Bodin, Ö. (2018). Fishing strategy diversification and fishers' ecological dependency. Ecol. Soc. 23:28. doi: 10.5751/ES-10211-230328

Young, O. R., Webster, D. G., Cox, M. E., Raakjær, J., Blaxekjær, L. Ø., Einarsson, N., et al. (2018). Moving beyond panaceas in fisheries governance. Proc. Natl. Acad. Sci.U.S.A. 115, 9065-9073. doi: 10.1073/pnas.1716545115

Conflict of Interest: The authors declare that the research was conducted in the absence of any commercial or financial relationships that could be construed as a potential conflict of interest.

Copyright (c) 2021 Kriegl, Elías Ilosvay, von Dorrien and Oesterwind. This is an open-access article distributed under the terms of the Creative Commons Attribution License (CC BY). The use, distribution or reproduction in other forums is permitted, provided the original author(s) and the copyright owner(s) are credited and that the original publication in this journal is cited, in accordance with accepted academic practice. No use, distribution or reproduction is permitted which does not comply with these terms. 